\title{
Geochemical Modeling of Trace Element Release from Biosolids
}

\author{
Defne S. Apul, ${ }^{1, *}$ Maria E. Diaz, ${ }^{2}$ Jon Petter Gustafsson, ${ }^{3}$ and Lakhwinder S. Hundal ${ }^{4}$ \\ Departments of ${ }^{1}$ Civil Engineering and ${ }^{2}$ Chemical Engineering, University of Toledo, Toledo, Ohio. \\ ${ }^{3}$ Department of Land and Water Resources Engineering, KTH (Royal Institute of Technology), Stockholm, Sweden. \\ ${ }^{4}$ Metropolitan Water Reclamation District of Greater Chicago, Research and Development Department Section 123, Cicero, Illinois.
}

Received: September 24, 2009 Accepted in revised form: May 28, 2010

\begin{abstract}
Biosolids-borne trace elements may be released to the environment when biosolids are used as fertilizers in farm land. Trace element leachate concentrations from biosolids are known to be limited by both organic and inorganic sorbent surfaces; this experimental evidence has not been previously verified with geochemical modeling of sorption reactions. In this study, $\mathrm{pH}$-dependent leaching experiments and sorption isotherm experiments were coupled with a multisurface geochemical modeling approach. Biosolids samples were obtained from Toledo and Chicago wastewater treatment plants; their sorbent surfaces were defined and modeled as a combination of organic matter (OM) and Fe-, $\mathrm{Al}-$, and Mn-oxides. The multisurface geochemical modeling approach was partially successful in predicting the $\mathrm{pH}$-dependent leachate concentrations of $\mathrm{As}, \mathrm{Cd}, \mathrm{Cr}, \mathrm{Cu}, \mathrm{Mo}, \mathrm{Ni}$, and $\mathrm{Zn}$. Both modeled and experimental data indicated that As and Mo in biosolids were bound to Fe-oxides; Cd, Cr, and $\mathrm{Cu}$ were bound mainly to $\mathrm{OM}$; and as $\mathrm{pH}$ increased the fractions of $\mathrm{Cd}$ and $\mathrm{Cu}$ bound to Fe-oxides in the biosolids matrix increased. $\mathrm{Ni}$ and $\mathrm{Zn}$ were distributed between $\mathrm{OM}$ and Fe-oxides, and the percentage of each fraction depended on the $\mathrm{pH}$. This study showed that the multisurface geochemical model could be used to generate As (and to a lesser extent Cd) Freundlich isotherm parameters for biosolids. However, the composition and reactivity of solid and dissolved $\mathrm{OM}$ was identified as a source of uncertainty in the modeling results. Therefore, more detailed studies focusing on the reactivity of isolated biosolids OM fractions with regard to proton and metal binding are needed to improve the capability of geochemical models to predict the fate of biosolids-borne trace metals in the environment.
\end{abstract}

Key words: biosolids; Visual MINTEQ; modeling; metal leaching; multisurface modeling

\section{Introduction}

B IOSOLIDS ARE A byproduct of municipal wastewater treatment process that meet the regulatory requirements for recycling as specified in the U.S. Environmental Agency's 40 CFR Part 503 Rule (McFarland, 2001). Biosolids contain large amounts of nutrients such as $\mathrm{N}, \mathrm{P}, \mathrm{K}$, and organic carbon (OC) that make them an excellent fertilizer. However, biosolids may also contain detectable levels of trace metals and As, which may pose human health and ecological risks if released to the environment.

There is a large body of literature on the fate and transport of trace metals and As from land-applied biosolids (Haynes et al., 2009). It is now well known that only a fraction of the total trace element concentrations is available in biosolids (Haynes et al., 2009) and other contaminated matrices (Kosson et al., 2002). To evaluate the availability of trace elements,

${ }^{*}$ Corresponding author: Department of Civil Engineering, University of Toledo, $2801 \mathrm{~W}$. Bancroft St., MS 307, Toledo, OH 43606. Phone: 419530 8132; Fax: 419530 8116; E-mail: defne.apul@utoledo .edu sequential fractionation methods have been used and concentrations of trace elements in operationally defined biosolids fractions have been reported (Alvarez et al., 2002; Alonso et al., 2006). Yet, the interpretation of these data can be difficult because of lack of specificity, selectivity, and validity of sequential fractionation methods (Kot and Namiesńik, 2000). In equilibrium conditions, trace element availability in contaminated matrices is dictated by relevant sorption (Meima and Comans, 1998) or dissolution/precipitation reactions (Mijno et al., 2004) and these reactions are largely affected by $\mathrm{pH}$. Thus, leaching the contaminated matrix at varying $\mathrm{pH}$ conditions can be an effective alternative method for assessing the solubility and availability of trace elements in contaminated matrices (Kosson et al., 2002). Batch pH-dependent leaching experiments have been successfully coupled with geochemical modeling to evaluate the processes that control metal release from natural aquatic sediments (Davis et al., 1998; Wen et al., 1998), contaminated soils (Weng et al., 2001; Dijkstra et al., 2004, 2009; Khai et al., 2008), steel slag (Apul et al., 2005), and municipal solid waste incinerator bottom ash (Meima and Comans, 1998). In geochemical modeling of these complex matrices, a multisurface approach can be used, in which 
aqueous complexation reactions, surface complexation reactions for different metal oxides, and cation-humic substance interactions are simultaneously simulated.

The multisurface geochemical modeling approach also holds promise for addressing some knowledge gaps related to the availability of trace elements in biosolids. The relative importance of organic and inorganic sorbents in biosolids has been a topic of controversy (Basta et al., 2005). It has been hypothesized that following the cessation of application of organic byproducts such as biosolids, bound trace metals and As would be released into soluble forms due to loss of organic fraction, which occurs because of natural decomposition of organic matter (OM) and soil acidification (McBride, 1995). Prior experimental research has shown that the retention of trace metals in biosolids is attributed to not only the presence of $\mathrm{OM}$ but also oxides of iron (Fe), manganese $(\mathrm{Mn})$, and $\mathrm{Al}$ (Merrington and Smernik, 2004; Basta et al., 2005; Hettiarachchi et al., 2006). Although it is known that both organic and inorganic surfaces play a role in metal availability from biosolids, the reactions between metals and these surfaces have not been previously investigated using the multisurface geochemical modeling approach; a description of the geochemical reactions affecting trace element availability has been missing in the literature.

The goal of this research was to improve the knowledge on how As and trace metals $(\mathrm{Cd}, \mathrm{Cr}, \mathrm{Cu}, \mathrm{Mo}, \mathrm{Ni}, \mathrm{Pb}$, and $\mathrm{Zn})$ partition between organic and inorganic phases in the complex environmental matrix of biosolids and make use of this information to predict the release of these elements into solution. It was hypothesized that the biosolids matrix could be defined as a combination of minerals such as $\mathrm{Fe}-$, $\mathrm{Al}-$, and Mn-oxides, and OM such as fulvic acids (FAs) and humic acids (HAs), and that a multisurface geochemical modeling approach could be used to predict the solid-solution equilibrium concentrations of trace metals and As. A surface complexation modeling approach (Dzombak and Morel, 1990) was coupled with NICA-Donnan model (Kinniburgh et al., 1999) to develop a multisurface geochemical model for biosolids. To achieve a general validity of the modeling approach, the surface complexation and NICA-Donnan models and associated parameter sets were not modified; in addition, only published thermodynamic and binding parameters were used without parameter fitting. The research hypothesis was evaluated by comparing model predictions to experimental data obtained from (1) equilibration experiments over a wide range of $\mathrm{pH}$, and (2) isotherm experiments for As (anionic species) and Cd (cationic species). The developed model was also used to evaluate the importance of organic and inorganic surfaces in the retention of trace elements in the biosolids matrix.

\section{Materials and Methods}

A general scheme of how the multisurface geochemical modeling approach was used is presented in Fig. 1. The container on the left represents the experiments that were carried out to determine the necessary input parameters. The $\mathrm{pH}$-dependent leaching experiments yielded the $\mathrm{pH}$, dissolved OC (DOC), dissolved ions (background analytes concentrations of $\mathrm{SO}_{4}{ }^{2-}, \mathrm{PO}_{4}{ }^{3-}, \mathrm{Na}^{+}, \mathrm{NO}_{3}{ }^{-}, \mathrm{Mn}^{2+}, \mathrm{Mg}^{2+}, \mathrm{K}^{+}$, $\mathrm{SiO}_{4}{ }^{4-}, \mathrm{Fe}^{3+}, \mathrm{Cl}^{-}, \mathrm{Ca}^{2+}, \mathrm{CO}_{3}{ }^{2-}, \mathrm{Al}^{3+}$, and $\mathrm{F}^{-}$), and total available trace element concentrations ( $\mathrm{As}, \mathrm{Cd}, \mathrm{Cu}, \mathrm{Cr}, \mathrm{Mo}$, $\mathrm{Pb}, \mathrm{Ni}$, and $\mathrm{Zn}$ ). In modeling the $\mathrm{pH}$-dependent leaching of trace elements, the total available concentration input in the model can be estimated from "availability" tests (Apul et al., 2005) or from the total dissolved concentration of the element measured at the lowest (for cationic species) and highest $\mathrm{pH}$ (for anionic species) for a large $\mathrm{pH}$ range such as from $\mathrm{pH}$ 2-4 to 12 (Dijkstra et al., 2008). In the present study, the highest dissolved concentration measured from the $\mathrm{pH}$-dependent leaching experiments was used as the total available concentration. This approach is often used in modeling instead of the total element concentration of the sample because only a fraction of the total metal content is available and this availability is pH dependent (Kosson et al., 2002). The selective chemical extractions yielded the concentrations of sorptive sites present in the system, which remained constant for all the simulations. The input parameters were introduced in the software along with the equilibrium constants for all the processes modeled and the model predicted the equilibration of the trace elements between the solid and aqueous phases for selected $\mathrm{pH}$ values. The model predictions were compared with the dissolved element concentrations measured in the equilibration experiments.

\section{Biosolids samples}

Biosolids characteristics may vary based on different wastewater treatment plants (Haynes et al., 2009). To evaluate the validity of the model, biosolids samples were obtained from two different wastewater treatment plants: Bay View wastewater treatment plant in Toledo, and Stickney Water Reclamation Plant of the Metropolitan Water Reclamation District of Greater Chicago. Toledo sample was collected in 2006 in an $\sim 2.5-\mathrm{kg}$ plastic container and brought to the
FIG. 1. General scheme for the multisurface geochemical modeling approach. DOC, dissolved organic carbon; FA, fulvic acid; HA, humic acid; HFO, hydrous ferric oxide; $\mathrm{HMO}$, hydrous manganese oxide.

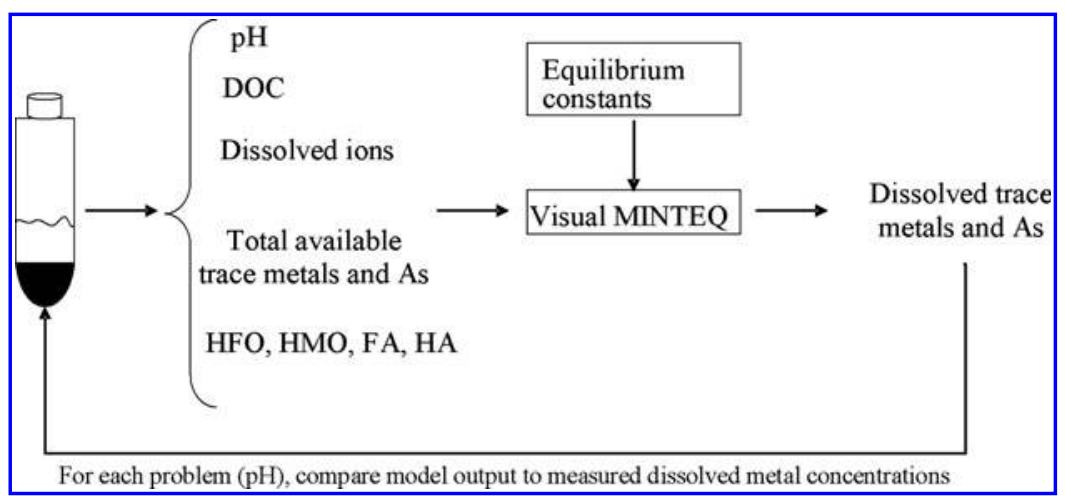


laboratory. Chicago sample $(1.5 \mathrm{~kg})$ was collected in 2005 and shipped in a glass container from Chicago to Toledo. Both samples were stored at $4^{\circ} \mathrm{C}$ until further processing, which took place within 1 month of collection. A subset of each sample was measured for its water content using ASTM Standard D 2216 (2005). The measured water content was used in estimating the dry mass basis of biosolids used in experiments.

\section{Sodium hydroxide extraction of $C$ from $O M$}

The method of Gustafsson and van Schaik (2003) was followed for the extraction of $\mathrm{C}$. Sequential extraction with $\mathrm{HCl}$ and $\mathrm{NaOH}$ was carried out to dissolve carbonates and $\mathrm{OM}$ (Fig. 2). About $1.00 \mathrm{~g}$ of sample (on a dry basis) was mixed with $20 \mathrm{~mL}$ of $0.02 \mathrm{M} \mathrm{HCl}$ and left to equilibrate for $16 \mathrm{~h}$ in a wrist-action shaker. The sample was centrifuged at 4,000 rpm for at least $15 \mathrm{~min}$ and the supernatant was separated and analyzed for total OC (TOC) and inorganic carbon (IC). The OC dissolved in this step was assumed to be from FAs and the IC was assumed to be carbonates. The remaining solid fraction was mixed with $20 \mathrm{~mL}$ of $0.1 \mathrm{M} \mathrm{NaOH}$ and left to equilibrate for $2 \mathrm{~h}$ in the wrist-action shaker. The sample was centrifuged at 4,000 rpm for at least $15 \mathrm{~min}$ and the supernatant was separated. The solid fraction was treated again with $0.1 \mathrm{M} \mathrm{NaOH}$ similarly to the previous step. The supernatants obtained from the two $\mathrm{NaOH}$ treatments were combined and two separate aliquots were obtained. The first aliquot was analyzed for TOC and IC; the OC dissolved in this step consisted of both FAs and HAs. The second aliquot was acidified with $0.02 \mathrm{M} \mathrm{HCl}$ to $\mathrm{pH} \mathrm{2,} \mathrm{which} \mathrm{would} \mathrm{cause} \mathrm{the} \mathrm{HAs} \mathrm{to}$ precipitate. The sample was centrifuged and the supernatant was separated and analyzed for TOC and IC. The OC dissolved in this step was assumed to be from FAs.

\section{Selective chemical extractions for metal oxides}

The experimental protocol of Dijkstra et al. (2004) was followed to obtain concentrations of reactive $\mathrm{Fe}-, \mathrm{Al}-$, and $\mathrm{Mn}$ (hydr)oxide surface sites involved in surface complexation of trace elements. All extractions were done in triplicates for each sample. Iron and manganese from amorphous and crystalline Fe- and Mn-oxides were extracted with dithionitecitrate (van Reeuwijk, 1992). Specifically, $1.00 \mathrm{~g}$ of dry sample was mixed with $50 \mathrm{~mL}$ of citrate-dithionite solution $(17 \%$ $[\mathrm{w} / \mathrm{v}] \mathrm{Na}_{3} \mathrm{C}_{6} \mathrm{H}_{5} \mathrm{O}_{7}$ and $1.7 \%$ [w/v $] \mathrm{Na}_{2} \mathrm{~S}_{2} \mathrm{O}_{4}$ ) and placed in a wrist-action shaker. The suspension was left to equilibrate for $16 \mathrm{~h}$. The sample was centrifuged for at least $15 \mathrm{~min}$ at $4,000 \mathrm{rpm}$. The supernatant was filtered and diluted 10 times with deionized water. The sample was analyzed for Fe and Mn with inductively coupled plasma-optical emission spectroscopy (ICP-OES).

The ascorbate extraction method of Kostka and Luther (1994) was used to quantify iron associated with amorphous (hydr)oxides. A mass of $1.00 \mathrm{~g}$ dry sample was mixed with $100 \mathrm{~mL}$ of the ascorbate buffer solution $\left(10 \mathrm{~g}\right.$ of $\mathrm{Na}_{3} \mathrm{C}_{6} \mathrm{H}_{5} \mathrm{O}_{7}$ and $10 \mathrm{~g}$ of $\mathrm{NaHCO}_{3}$ in $200 \mathrm{~mL}$ of deionized water, and $4 \mathrm{~g}$ of $\mathrm{C}_{6} \mathrm{H}_{8} \mathrm{O}_{6}$ for a final $\mathrm{pH}$ of 8.0 ) and placed in a wrist-action shaker. The suspension was left to equilibrate for $24 \mathrm{~h}$. The sample was centrifuged for at least $15 \mathrm{~min}$ at $4,000 \mathrm{rpm}$. The supernatant was filtered and diluted with deionized water. The sample was analyzed for Fe with ICP-OES.

To estimate the aluminum (hydr)oxide concentrations, $1.00 \mathrm{~g}$ of sample (on a dry basis) was mixed with $100 \mathrm{~mL}$ of oxalate buffer solution and placed in a wrist-action shaker (van Reeuwijk, 1992). The oxalate solution was prepared by mixing $500 \mathrm{~mL}$ of $0.2 \mathrm{M}\left(\mathrm{NH}_{4}\right)_{2} \mathrm{C}_{2} \mathrm{O}_{4} \cdot \mathrm{H}_{2} \mathrm{O}$ and $380 \mathrm{~mL}$ of $0.2 \mathrm{M} \mathrm{H}_{2} \mathrm{C}_{2} \mathrm{O}_{4} \cdot 2 \mathrm{H}_{2} \mathrm{O}$ to obtain a solution with $\mathrm{pH}$ 3.0. The suspension was left to equilibrate for $4 \mathrm{~h}$ in the dark. The

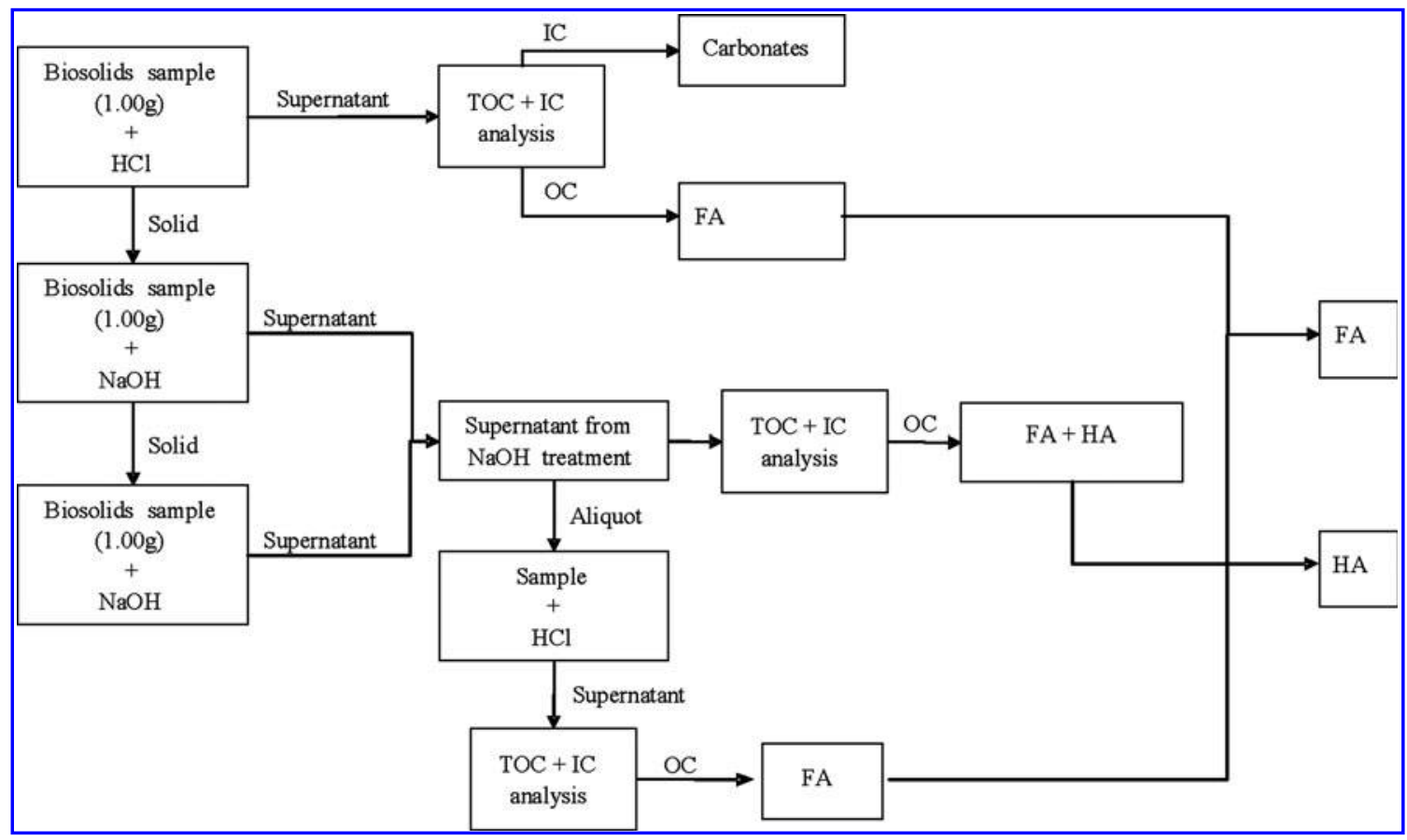

FIG. 2. Schematic of selective chemical extraction for OM. IC, inorganic carbon; OM, organic matter; TOC, total organic carbon. 
sample was centrifuged at 4,000 rpm for at least $15 \mathrm{~min}$, filtered, and then diluted five times. The supernatant was analyzed for total aluminum. It should be noted that the assignment of this fraction to aluminum (hydr)oxide is a simplification because in reality poorly ordered aluminosilicates and organically bound aluminum may also be included in this fraction.

\section{Equilibration experiments}

Two types of equilibration experiments were conducted. In $\mathrm{pH}$-dependent leaching experiments, first the buffering capacity of a subsample was measured by adding acid ( $2 \mathrm{M}$ $\mathrm{HNO}_{3}$ ) or base (2 M NaOH) (Kosson et al., 2002) (see Supplemental Fig. S1). Using the buffering capacity of the subsample, the $\mathrm{pH}$ of other subsamples was adjusted to values ranging from 2 to 12 . The subsamples were then leached for $76 \mathrm{~h}$ in close containers (spherical-bottomed polycarbonate centrifuge bottles) placed in a wrist-action shaker. The liquid:solid ratio was $50 \mathrm{~L} / \mathrm{kg} ; 2.00 \mathrm{~g}$ biosolids (on a dry basis) was added to $100 \mathrm{~mL}$ of deionized water containing a background electrolyte concentration of $0.01 \mathrm{M} \mathrm{NaNO}_{3}$. After the agitation period, the subsamples were centrifuged at 2,500 rpm for $30 \mathrm{~min}$ and the subsamples' final $\mathrm{pH}$ and Eh were recorded. Three different aliquots were obtained from these $\mathrm{pH}$-dependent leaching experiments: the first aliquot was immediately placed in vials and analyzed using a Shimadzu TOC-VCSH TOC analyzer for OC and IC; the second aliquot was analyzed using a Dionex ICS-1000 Ion Chromatography System for $\mathrm{F}^{-}, \mathrm{Cl}^{-}, \mathrm{Br}^{-}, \mathrm{NO}_{2}{ }^{-}, \mathrm{NO}_{3}{ }^{-}, \mathrm{PO}_{4}{ }^{3-}$, and $\mathrm{SO}_{4}{ }^{2-}$; the third aliquot was filtered through a $0.2-\mu \mathrm{m}$ membrane filter, preserved with ultrapure $2 \mathrm{M} \mathrm{HNO}_{3}$, and refrigerated at $4{ }^{\circ} \mathrm{C}$ until analyzed for $\mathrm{Al}, \mathrm{As}, \mathrm{Ca}, \mathrm{Cd}, \mathrm{Cr}, \mathrm{Cu}, \mathrm{Fe}, \mathrm{K}$, $\mathrm{Mg}, \mathrm{Mn}, \mathrm{Mo}, \mathrm{Na}, \mathrm{Ni}, \mathrm{P}, \mathrm{Pb}, \mathrm{S}, \mathrm{Si}$, and $\mathrm{Zn}$ using ICP-OES. Further, to provide an estimate of the aromaticity and the "humic-like" characteristics of the dissolved $C$ in the batch experiments, the specific ultraviolet absorbance (SUVA) was measured at $254 \mathrm{~nm}$ for the "pH-dependent" extracts of the Toledo sample using a spectrophotometer.

Sorption equilibrium experiments were done and the leachate from them were processed in a way similar to the $\mathrm{pH}-$ dependent leaching experiments. However, no acid or base was added to the sample to adjust the $\mathrm{pH}$; instead, subsamples were spiked with $\mathrm{Cd}$ and As. A Cd standard solution $\left[\mathrm{Cd}\left(\mathrm{NO}_{3}\right)_{2} \cdot 4 \mathrm{H}_{2} \mathrm{O}\right]$ and As standard solution $\left(\mathrm{Na}_{2} \mathrm{HAsO}_{4}\right.$. $7 \mathrm{H}_{2} \mathrm{O}$ ) were quantitatively added to give a known $\mathrm{Cd}$ or As concentration. Spiking with various concentrations of As did not change the $\mathrm{pH}$ of the subsamples much (average and standard deviation of $\mathrm{pH}$ : $6.8 \pm 0.1$ ), but the Cd-spiked samples had a slightly higher $\mathrm{pH}$ (average and standard deviation of $\mathrm{pH}: 7.4 \pm 0.1$ ). The amounts of $\mathrm{Cd}$ or As sorbed were calculated using equation (1):

$$
q_{\mathrm{e}}=\frac{\left(C_{\mathrm{i}}-C_{\mathrm{e}}\right) V}{M}
$$

where $q_{\mathrm{e}}(\mu \mathrm{mol} / \mathrm{g})$ is the adsorbed As or Cd quantity per gram of biosolids, $M(\mathrm{~g})$ is the mass of biosolids, $V(\mathrm{~L})$ is the solution volume, and $C_{\mathrm{i}}(\mu \mathrm{M})$ and $C_{\mathrm{e}}(\mu \mathrm{M})$ are initial and equilibrium As or $\mathrm{Cd}$ concentrations.

All experiments were performed at standard laboratory conditions; room temperature was $\sim 20^{\circ} \mathrm{C}$. All glassware used in various experiments were washed first with a deter- gent, rinsed with deionized water three times, soaked in a $10 \%$ $\mathrm{HNO}_{3}$ acid bath for $8 \mathrm{~h}$, and then rinsed again with deionized water three times.

\section{Model platform}

The model was implemented in the Visual MINTEQ software (Gustafsson, 2009). Visual MINTEQ allows for the incorporation of aqueous complexation reactions, dissolution of minerals, and sorption processes. The equilibrium constants for most aqueous species are from the NIST compilation (Smith et al., 2003) and most constants for solid phases have been drawn from MINTEQA2 (USEPA, 1999).

\section{Modeling approach}

In an initial set of oxidation/reduction simulations, the Eh $(\mathrm{mV})$ and $\mathrm{pH}$ values and all dissolved species concentrations measured in equilibration experiments were input in the model; only aqueous complexation and oxidation/reduction reactions were allowed in these simulations. The oxidation/ reduction simulations showed that the primary species of As, $\mathrm{Mn}$, and $\mathrm{Cr}$ present in these conditions were $\mathrm{AsO}_{4}{ }^{3-}, \mathrm{Mn}^{2+}$, and $\mathrm{Cr}(\mathrm{OH})_{2}{ }^{+}$. Therefore, following the approach of Khai et al. (2008), in all other simulations, oxidation/reduction reactions were suppressed and As, $\mathrm{Mn}$, and $\mathrm{Cr}$ were input in Visual MINTEQ as $\mathrm{AsO}_{4}{ }^{3-}, \mathrm{Mn}^{2+}$, and $\mathrm{Cr}(\mathrm{OH})_{2}{ }^{+}$. Next, saturation indices (SI) were estimated. In the SI simulations, $\mathrm{pH}$ values and all dissolved species concentrations measured in equilibration experiments were input in the model; only aqueous complexation reactions and complexation to dissolved OM (DOM) were allowed. The model calculated the SI of the aqueous sample with respect to different possible mineral phases at each $\mathrm{pH}$ value. Finally, the leaching processes and sorption isotherms were simulated by including NICA-Donnan (Kinniburgh et al., 1999), surface complexation, and aqueous complexation reactions in the model configuration. To simulate $\mathrm{pH}$-dependent leaching, total available concentrations were input in the model for trace elements of interest (As, $\mathrm{Cd}, \mathrm{Cr}, \mathrm{Cu}, \mathrm{Mo}, \mathrm{Pb}, \mathrm{Ni}, \mathrm{Zn}$ ); these total available concentrations then partitioned among organic sorbent, inorganic sorbent, and aqueous phases. To simulate the effects of the background analytes, the dissolved concentrations of $\mathrm{SO}_{4}{ }^{2-}$, $\mathrm{PO}_{4}{ }^{3-}, \mathrm{Na}^{+}, \mathrm{NO}_{3}{ }^{-}, \mathrm{Mn}^{2+}, \mathrm{Mg}^{2+}, \mathrm{K}^{+}, \mathrm{SiO}_{4}{ }^{4-}, \mathrm{Fe}^{3+}, \mathrm{Cl}^{-}, \mathrm{Ca}^{2+}$, $\mathrm{CO}_{3}{ }^{2-}, \mathrm{Al}^{3+}$, and $\mathrm{F}^{-}$were input in the model as fixed values for each $\mathrm{pH}$; thus, for background analytes, the model calculated the sorbed concentrations while the dissolved concentrations remained fixed (Dijkstra et al., 2004). Sorption simulations were conducted in exactly the same way as $\mathrm{pH}$ dependent leaching simulations except that the total available concentrations input as As or Cd varied for each isotherm point based on total As or Cd in the system.

In simulating $\mathrm{pH}$-dependent leaching and sorption isotherms, the inorganic sites present in the system were assumed to be Fe-, Al-, and Mn-(hydr)oxides. Ideal solution was assumed; therefore, the activity of solids present could be quantified as their molar concentration in the overall solid solution. The diffuse layer surface complexation model for specific binding of cations and (oxy)anions to hydrous ferric oxide (HFO) (Dzombak and Morel, 1990) was included to account for sorption onto amorphous and crystalline Fe- and Al-oxides according to Dijkstra et al. (2004) and Apul et al. (2005), and the diffuse layer surface complexation model with 
constants from Tonkin et al. (2004) was included to account for sorption onto Mn-oxides.

The specific surface areas used in the model for amorphous and crystalline HFO were 600 and $100 \mathrm{~m}^{2} / \mathrm{g}$, respectively (Dzombak and Morel, 1990; Dijkstra et al., 2004). The total amount of amorphous HFO was calculated from Fe concentration obtained from the ascorbate extraction (Fe-Asc) (Dijkstra et al., 2004). The difference between Fe concentration from the dithionite extraction (Fe-Dith) and Fe-Asc was used to calculate the total amount of crystalline HFO (Dijkstra et al., 2004). The total amount of Al-oxides was estimated using oxalate extraction data (Al-Ox), and their specific surface area and site density were assumed to be the same as for HFO (Dijkstra et al., 2004). The concentration of hydrous manganese oxides (HMO) was calculated using a specific area of $746 \mathrm{~m}^{2} / \mathrm{g}$ (Tonkin et al., 2004); total amount of HMO was calculated from $\mathrm{Mn}$ concentration obtained from the dithionite extraction (Mn-Dith).

The reactive OM was assumed to be composed of only FAs and HAs. The NICA-Donnan model (Kinniburgh et al., 1999) with generic parameters (Milne et al., 2003) was included to describe the interaction between cations and humic substances. The inputs required by this model are total concentration of FAs, HAs, DOC, the percentage of the DOC that is active DOM (ADOM), and the percentage of ADOM that is FA. Total concentrations of FAs and HAs were calculated from OC concentrations measured in the selective chemical extraction. FAs and HAs were assumed to be composed of $50 \% \mathrm{C}$ and $60 \% \mathrm{C}$, respectively (McBride, 1994; Weng et al., 2002). The percentage of ADOM assumed to be FAs was set at $100 \%$; however, if there is not enough total FA to make up the total ADOM the model adjusted this parameter so that HA could contribute to ADOM. The ADOM/DOC ratio was set at the default value provided by Visual MINTEQ (1.4); this is close to the value of 1.3 that has been found to work well for soil systems in earlier modeling work (Weng et al., 2002; Gustafsson and Kleja, 2005). However, because the properties of biosolids DOM is not well known, the present study included model simulations in which a lower ADOM/DOC ratio was used (0.25; see Results section).

\section{Freundlich model parameter estimation}

Isotherm data from experiments are often modeled using the Langmuir and Freundlich isotherm models, the former typically providing better fits for systems with single, homogenous sorbents and the latter providing better fits for systems with multiple, heterogeneous sorbents with variable binding affinities (Benjamin, 2001). These two models have only two parameters but can provide good descriptions of some isotherms (Benjamin, 2001). The experimental or modeled data in the present study could not be represented with the Langmuir isotherm. However, parameters for the Freundlich isotherm model were determined using the linearized form of the Freundlich equation:

$$
\log q_{\mathrm{e}}=\log K_{\mathrm{f}}+n \log C_{\mathrm{e}}
$$

where $q_{\mathrm{e}}(\mu \mathrm{mol} / \mathrm{g})$ is the adsorbed As or Cd quantity per gram of biosolids, $C_{\mathrm{e}}(\mu \mathrm{M})$ is the equilibrium As or Cd concentration, and $K_{\mathrm{f}}$ and $n$ are the constants of the Freundlich isotherm.

\section{Results and Discussion}

\section{Selective chemical extractions}

Results from selective chemical extractions and relevant data collected from the literature are shown in Table 1. In general, the Toledo sample had higher concentrations of sorbents than the Chicago sample (Table 1). High concentrations of carbon in both samples suggest that OM is the most abundant sorbent. Carbon in FA and HA fractions were evenly distributed in the Toledo sample. The Chicago sample contained more FA but much less HA than the Toledo sample. The FA and HA contents of both samples were lower than those reported for New York City biosolids (Jaynes et al., 2003). The HA content in the Chicago sample was comparable to the HA content of soils but the FA contents of both samples were much higher than those reported for soils (Dijkstra et al., 2004).

Amorphous and crystalline forms of Fe-oxides were the most abundant inorganic sites in both samples. The Fe- and Mn-oxide concentrations in the Chicago sample were higher than the concentrations observed for soils (Dijkstra et al., 2004). Toledo sample had much higher inorganic site concentrations than those of the Chicago sample and those reported for soils (Dijkstra et al., 2004). Both samples also had much higher Fe- and Mn-oxide concentrations than those reported for Brisbane, Australia biosolids (Burton et al., 2003).

Table 1. Results from Selective Chemical Extractions

\begin{tabular}{lccc}
\hline & Chicago sample & Toledo sample & Literature data \\
\hline Natural pH & $7.36 \pm 0.01$ & $6.67 \pm 0.01$ & \\
Fe-Asc (mmol Fe/kg \pm SD) & $134.3 \pm 12.5$ & $471.0 \pm 23.3$ & $\left(1-54^{\mathrm{a}}\right)$ \\
$\mathrm{Fe}-\mathrm{Dith}(\mathrm{mmol} \mathrm{Fe} / \mathrm{kg} \pm \mathrm{SD})$ & $270.4 \pm 7.2$ & $1,330.5 \pm 41.2$ & $\left(12-179^{\mathrm{a}}\right)\left(27^{\mathrm{b}}\right)$ \\
$\mathrm{Al}-\mathrm{Ox}(\mathrm{mmol} \mathrm{Al} / \mathrm{kg} \pm \mathrm{SD})$ & $85.2 \pm 11.1$ & $163.1 \pm 3.6$ & $\left(2-111^{\mathrm{a}}\right)$ \\
Mn-Dith (mmol Mn/kg $\pm \mathrm{SD})$ & $15.8 \pm 0.5$ & $89.2 \pm 3.6$ & $\left(2.55^{\mathrm{b}}\right)$ \\
Extractable fulvic acid (mol C/kg $\pm \mathrm{SD})$ & 5.7 & $4.0 \pm 0.2$ & $\left(13.7^{\mathrm{C}}\right)\left(0.04-0.16^{\mathrm{a}}\right)$ \\
Extractable humic acid (mol C/kg $/ \mathrm{SD})$ & 0.4 & $4.6 \pm 0.5$ & $\left(11.1^{\mathrm{c}}\right)\left(0.08-0.83^{\mathrm{a}}\right)$ \\
\hline
\end{tabular}

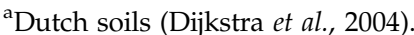

${ }^{\mathrm{b}}$ Australia biosolids (Burton et al., 2003). Following the method of Tessier et al. (1979), $0.04 \mathrm{M} \mathrm{NH}_{2} \mathrm{OH} \cdot \mathrm{HCl}$ was used in Fe- and Mn-oxide extractions.

${ }^{\mathrm{C}}$ New York City biosolids (Jaynes et al., 2003).

$\mathrm{SD}$, standard deviation for the three replicates.
} 


\section{Possible dissolved phases}

Visual MINTEQ database included 208 possible mineral phases for the chemical species measured in the present study. Of these 208 mineral phases, 8 were found to be in possible equilibrium (i.e., $-1<\mathrm{SI}<1$ for most $\mathrm{pH}$ values): quartz $\left(\mathrm{SiO}_{2}\right)$, chalcedony $\left(\mathrm{SiO}_{2}\right)$, cristobalite $\left(\mathrm{SiO}_{2}\right)$, gypsum $(\mathrm{Ca}-$ $\left.\mathrm{SO}_{4} \cdot 2 \mathrm{H}_{2} \mathrm{O}\right)$, calcite $\left(\mathrm{CaCO}_{3}\right)$, zincite $(\mathrm{ZnO}), \mathrm{ZnCO}_{3}$, and $\mathrm{Ca}_{3}\left(\mathrm{PO}_{4}\right)_{2}$ (am2). Quartz has been reported to be the main mineral component in biosolids (Hsiau and Lo, 1997). Carbonate, silicate, and phosphate phases have also been reported as partially responsible for retention of trace metals in biosolids (Merrington and Smernik, 2004; Basta et al., 2005; Hettiarachchi et al., 2006). But these sorption processes were not modeled in the present study because there is a scarcity of literature data on surface complexation reaction parameters for these sorbents. Attempts to model zincite and $\mathrm{ZnCO}_{3}$ dissolution to predict dissolved concentrations of $\mathrm{Zn}$ were not successful. The dissolution of the other six relevant minerals was modeled both individually and simultaneously in an attempt to predict dissolved concentrations of the background analytes; however, combining dissolution of minerals with sorption models in a system with multiple components led to computer model errors; therefore, dissolution and precipita- tion equilibriums of mineral phases were not modeled. Instead, the species included in these minerals were considered as background analytes and their aqueous concentrations were fixed in the $\mathrm{pH}$-dependent leaching and sorption isotherm simulations.

\section{Oxyanions}

The available As concentration for Toledo $(0.6 \mathrm{mg} / \mathrm{L})$ and Chicago $(0.4 \mathrm{mg} / \mathrm{L})$ samples were similar (Fig. 3). The $\mathrm{pH}-$ dependent leachate concentrations of As varied by almost 100 times for the Toledo sample and by only about 5 times for the Chicago sample. Ito et al. (2001) observed higher As availability $(7.0 \mathrm{mg} / \mathrm{L})$ in Japanese biosolids. However, similar to the Chicago sample, the As leachate concentrations from Japanese biosolids also only slightly increased with $\mathrm{pH}$ (from 1.5 to $7.0 \mathrm{mg} / \mathrm{L}$ from $\mathrm{pH} 1$ to 11). Dissolved concentrations of As were lowest around $\mathrm{pH} 5$. As the $\mathrm{pH}$ increased, the amount of As dissolved also increased. This observation is likely due to As binding to iron oxides in oxidizing environments (Hartley et al., 2004; Sracek et al., 2004); the surface charge of the iron oxides changes with $\mathrm{pH}$ from positive charge at lower $\mathrm{pH}$ values, which attracts the anions to negative charge at higher $\mathrm{pH}$ values, which then repels the anions.
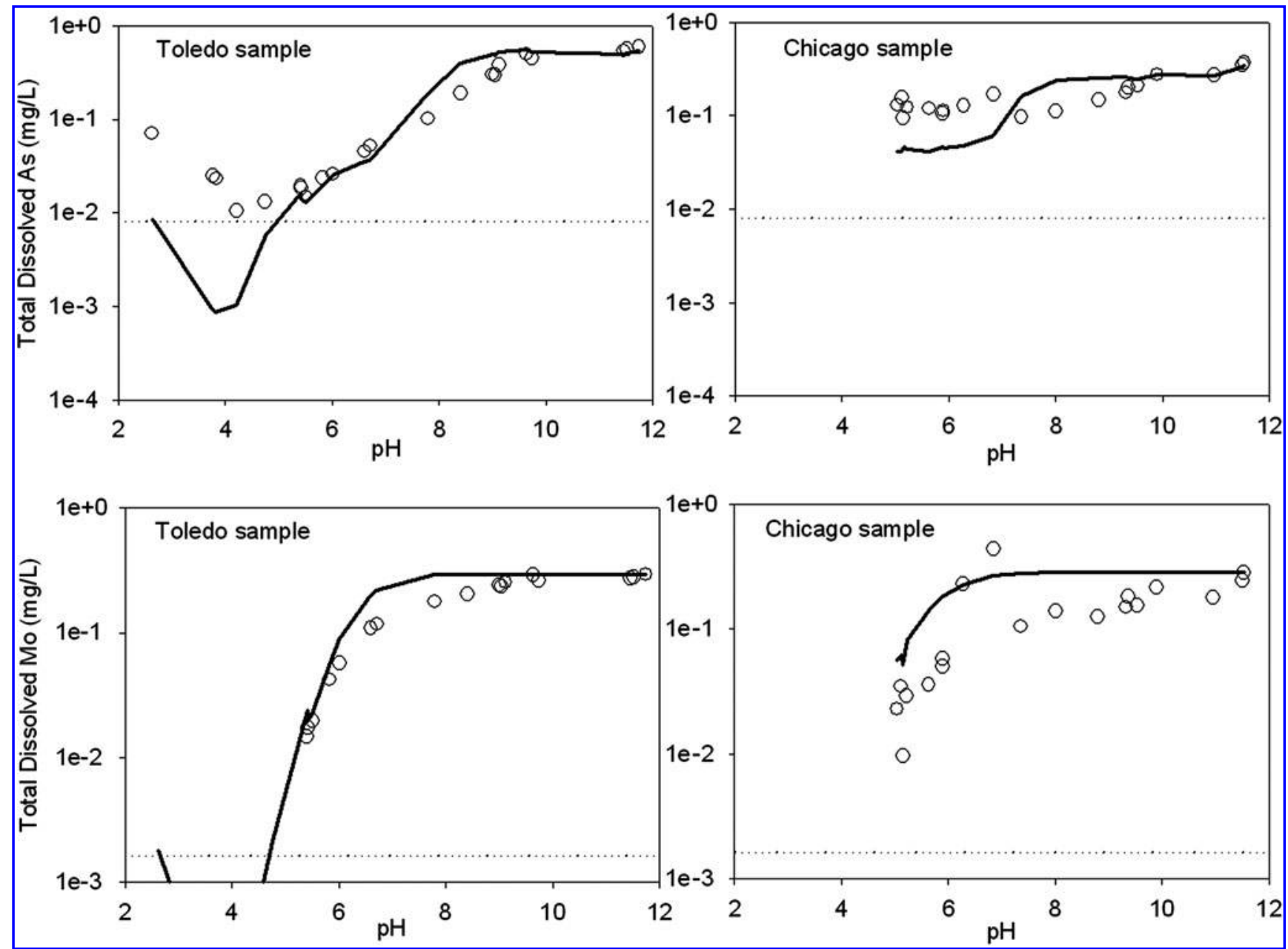

FIG. 3. Experimental (circles) and modeled (solid lines) results for As and Mo. Dotted line represents the method detection limit. 
The match between the modeled and experimental data were good for both samples but much better for the Toledo sample except below $\mathrm{pH} 5$ at which the model underestimated the dissolved concentration by more than an order of magnitude. One limitation of this modeling approach is that the concentration of Fe-oxides is kept constant throughout the $\mathrm{pH}$ range, when in reality some dissolution of Feoxides occurs at low $\mathrm{pH}$ values, which could account for the failure of the model at lower $\mathrm{pH}$. Since the model only accounts for As sorption onto HFO, based on the modeling results it can be assumed that this sorption process dictated the binding of As in biosolids.

Total dissolved concentration of Mo displayed a similar pattern to that of As; concentrations increased with increasing $\mathrm{pH}$. The model predicted that for $\mathrm{pH}$ values above 7, Mo was completely dissolved; however, in the $\mathrm{pH}$-dependent experiments it was observed that the dissolved concentration of Mo increased with increasing $\mathrm{pH}$. Increasing concentrations of Mo with increasing $\mathrm{pH}$ values as obtained in our model and $\mathrm{pH}$-dependent leaching experiments are in good agreement with McBride et al. (2004), who found that $\mathrm{CaCl}_{2}$-extractable soil Mo increased as the $\mathrm{pH}$ increased.

\section{ADOM/DOC ratio}

To the authors' knowledge, the reactivity of the biosolids DOM in terms of proton and metal binding has not been previously reported for biosolids; therefore, the ADOM/DOC ratio is likely to represent a considerable uncertainty in the case of cationic elements (for oxyanions such as As and Mo, this parameter is of very little importance because As does not interact directly with OM in the model). It has been reported that biosolids humic compounds have a lower content of functional groups (carboxyls and phenolic hydroxyls) when compared with typical soils and other organic amendments (Sposito et al., 1982; Boyd and Sommers, 1990; Pandeya and Singh, 2000; Bergkvist, 2003).

The SUVA determinations carried out for Toledo biosolids indicate a very low aromaticity of the extracted DOM (see Supplemental Fig. S2); on average the SUVA value was $0.62 \mathrm{~L} /(\mathrm{mg} \cdot \mathrm{C} \cdot \mathrm{m})$ across a range of $\mathrm{pH}$ values. Natural FAs and HAs commonly have SUVA values between 3 and $6 \mathrm{~L} /$ (mg · C · m) (Amery et al., 2008; Yang et al., 2008). This lends some additional support to the idea that the extracted DOM from biosolids may have weaker proton- and metal-binding properties than pure FAs or HAs. In the model, one can try to account for this by using a lower ADOM/DOC ratio than the one used for soil systems (1.3-1.4). The use of a lower ADOM/ DOC ratio also provided better fits (in terms of lower rootmean square errors) for some trace metals. Therefore, included in results is a second model simulation in which the $\mathrm{ADOM} / \mathrm{DOC}$ ratio was set at a very low value (0.25). It is possible that the "real" ratio is somewhere between these extremes (0.25-1.4). A related problem is the uncertainty of the values for solid-phase HA and FA in biosolids. In the model the $\mathrm{NaOH}$ is assumed to quantitatively extract $\mathrm{OM}$ as HA and FA; this assumption seems to work well for soils (Gustafsson and van Schaik, 2003; Dijkstra et al., 2009). If, for biosolids, only a minor part of the OM is HA and FA, the model results for cationic elements will indicate weaker binding to HA and FA, which in turn will increase the dissolved concentration of these elements.

\section{Cations}

Both samples contained approximately equal concentration of available $\mathrm{Cd}$ and both samples displayed a very similar release pattern as a function of $\mathrm{pH}$ with minimum release occurring around neutral $\mathrm{pH}$ values (Fig. 4). The model with an ADOM/DOC ratio of 1.4 overestimated the dissolved concentrations of $\mathrm{Cd}$, particularly between $\mathrm{pH} 5$ and 8. After adjusting the ADOM/DOC ratio to 0.25 the model prediction for $\mathrm{Cd}$ for $\mathrm{pH}$ values below 8 improved considerably, providing good agreements with the experimental data, especially for the Toledo sample. For the Chicago sample, the adjusted model provided an improvement in its predictions; however, it still overestimated the dissolved concentrations for most of the $\mathrm{pH}$ range. Even the adjusted model predicted that $\mathrm{Cd}$ was mostly bound to $\mathrm{OM}$ (Table 2). Cd has very low affinity for HFO (Meima and Comans, 1998); however, some of the Cd was sorbed on HFO in the basic $\mathrm{pH}$ range.

$\mathrm{Cr}$ and $\mathrm{Cu}$ showed a similar dissolution pattern as a function of $\mathrm{pH}$ with considerably less release occurring between pH 4 and 6 (Fig. 4). Above $\mathrm{pH}$ 5, $\mathrm{Cr}$ and $\mathrm{Cu}$ concentrations increased, possibly because of the complexation with DOM. DOC concentration also increased in this $\mathrm{pH}$ range (see Supplemental Fig. S3). The model speciation results show that most of the dissolved $\mathrm{Cr}(\sim 100 \%)$ and $\mathrm{Cu}(>90 \%)$ formed complexes with DOM in this $\mathrm{pH}$ range. Using an ADOM/ DOC ratio of 1.4, the model showed a good agreement with the experimental data in the basic $\mathrm{pH}$ range but overestimated the dissolved concentrations in the acid $\mathrm{pH}$ range. In contrast, the model with a low ADOM/DOC ratio considerably improved the predictions for $\mathrm{Cr}$ and $\mathrm{Cu}$ in the acid side of the $\mathrm{pH}$ range, but provided poorer fits in the more alkaline $\mathrm{pH}$ range. $\mathrm{OM}$ was found to be the predominant reactive surface for $\mathrm{Cr}$ and $\mathrm{Cu}$ (Table 2), although at higher $\mathrm{pH}$ values the small fraction of $\mathrm{Cu}$ remained sorbed was found to be bound to Feoxides. Using the method of sequential extractions of Tessier et al. (1979), other researchers also found that $\mathrm{Cu}$ was mostly bound to OM or was a part of the residual fraction of the biosolids matrix (McLaren and Clucas, 2001; Burton et al., 2003).

Chicago and Toledo samples showed a similar dissolution pattern for $\mathrm{Ni}$ as a function of $\mathrm{pH}$; minimum release of $\mathrm{Ni}$ occurred around neutral $\mathrm{pH}$ (Fig. 5). Overall, the model using a higher ADOM/DOC ratio was able to describe the Ni results very well for both samples and there was very small difference in the outputs of the original and adjusted models in the acidic $\mathrm{pH}$ range. In the alkaline $\mathrm{pH}$ range, the model with a low ADOM/DOC ratio underestimated the total dissolved Ni for both samples.

In the geochemical model, $\mathrm{Ni}$ was bound to $\mathrm{OM}$ and oxides of iron (Table 2), which is in good agreement with the findings of McLaren and Clucas (2001), who reported that $\mathrm{Ni}$ was bound to the metal oxides and $\mathrm{OM}$ at high $\mathrm{pH}$. Most of the sorbed $\mathrm{Ni}$ was bound to $\mathrm{OM}$ at low $\mathrm{pH}$ values and to $\mathrm{HFO}$ at higher $\mathrm{pH}$ values. Analysis of the adjusted model for the Toledo sample suggested that in the acid $\mathrm{pH}$ range, dissolved $\mathrm{Ni}$ was primarily as a free metal ion with $>50 \%$ of dissolved $\mathrm{Ni}$ found as a free metal ion at $\mathrm{pH} 6.7$; however, Ni formed complexes with DOM at higher $\mathrm{pH}$ values with $96 \%$ of dissolved $\mathrm{Ni}$ complexed with DOM at pH 7.8. 

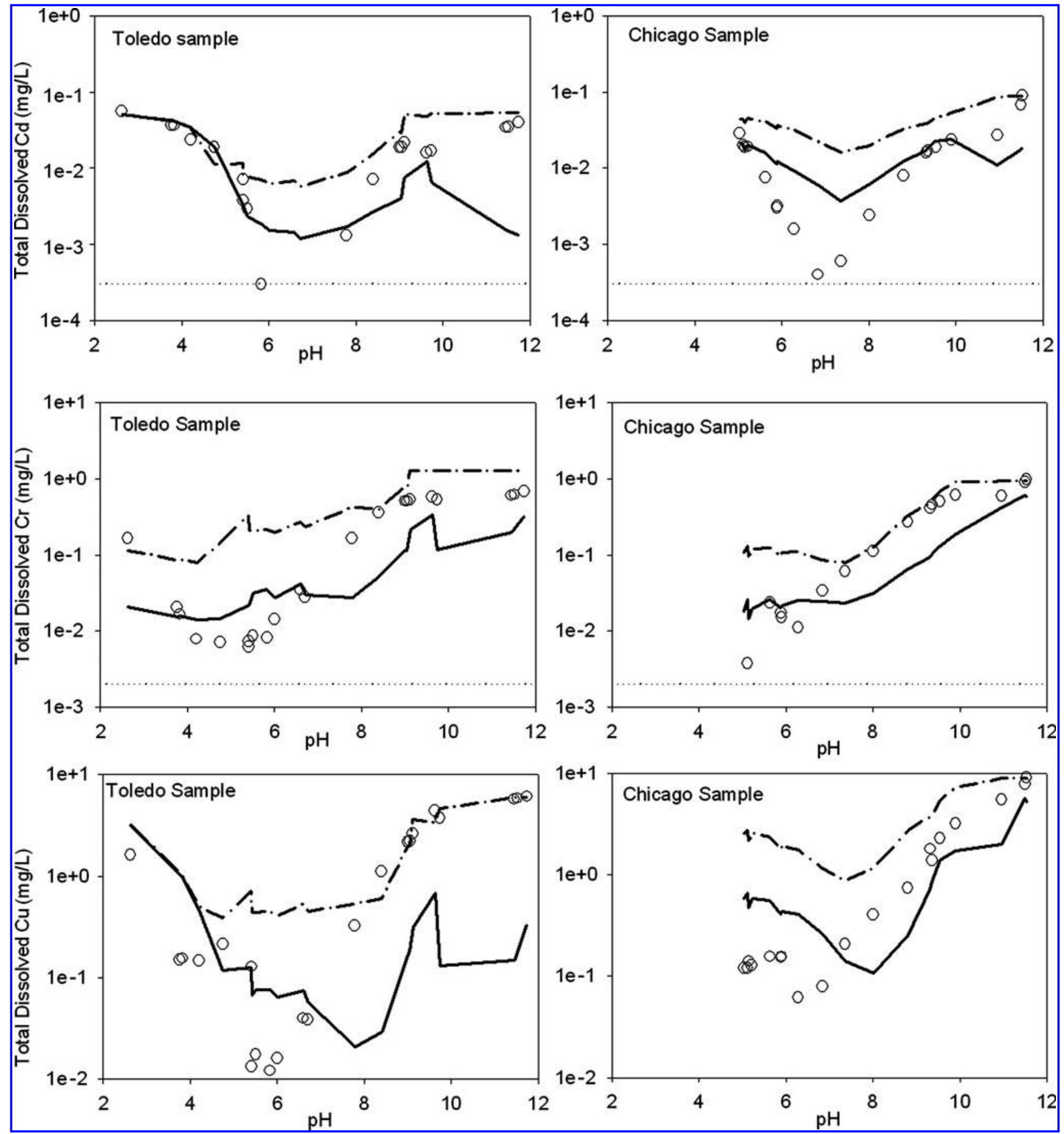

FIG. 4. Experimental (circles), model with $\mathrm{ADOM} / \mathrm{DOC}=1.4$ (dashed line), and model with $\mathrm{ADOM} / \mathrm{DOC}=0.25$ (solid line) results for $\mathrm{Cd}, \mathrm{Cr}$, and $\mathrm{Cu}$. Dotted horizontal line represents the method detection limit. ADOM, active dissolved organic matter.

Dissolved concentrations of $\mathrm{Pb}$ were below the method detection limit in acidic conditions, but both samples showed an increasing concentration with increasing $\mathrm{pH}$ in basic conditions (Fig. 5). The model for Toledo was unsuccessful in predicting the dissolved $\mathrm{Pb}$ concentrations. At $\mathrm{pH}>8$, the model for Chicago sample was in good agreement with the experimental data and $\mathrm{Pb}$ was primarily bound to $\mathrm{HMO}$ in this $\mathrm{pH}$ range. The adjusted model largely underestimated $\mathrm{Pb}$ leachate concentrations.

Minimum release of $\mathrm{Zn}$ occurred around neutral $\mathrm{pH}$ for both samples (Fig. 5). For the Toledo sample there was no difference between the predictions of the two models in the acid $\mathrm{pH}$ range; in the alkaline range the adjusted model underestimated the dissolved $\mathrm{Zn}$ concentrations more than the unadjusted model. For the Chicago sample, the model 


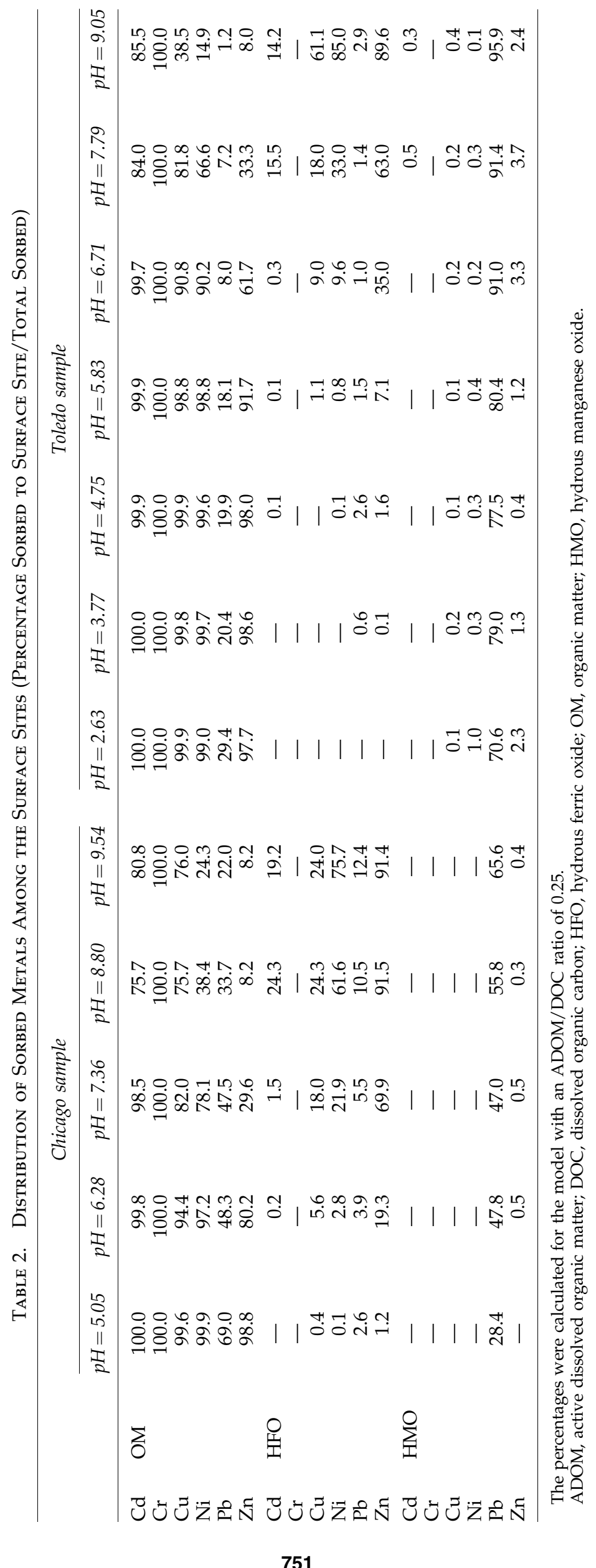



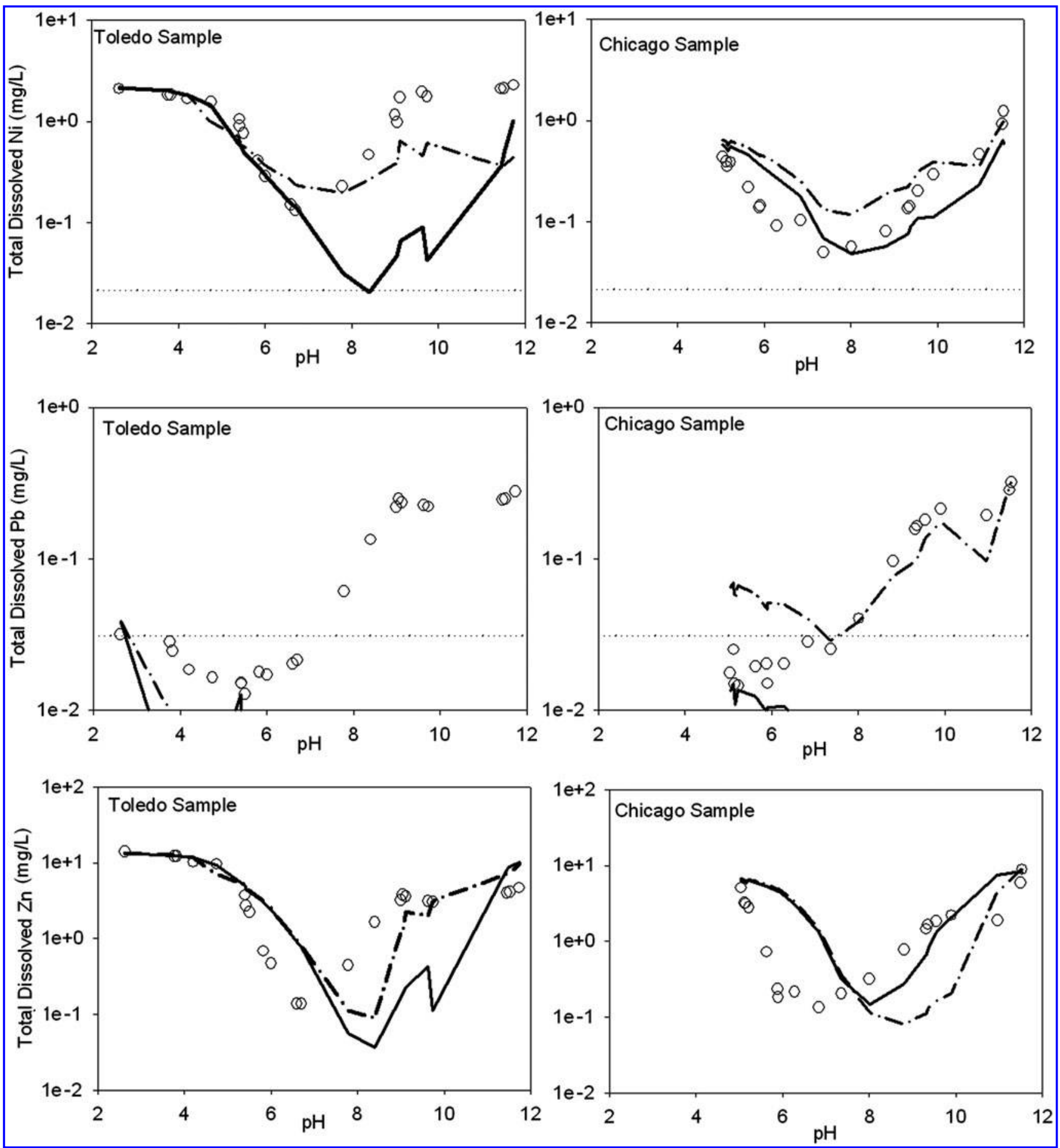

FIG. 5. Experimental (circles), model with ADOM/DOC $=1.4$ (dashed line), and model with ADOM/DOC $=0.25$ (solid line) results for $\mathrm{Ni}, \mathrm{Pb}$, and $\mathrm{Zn}$. Dotted line represents the method detection limit.

employing a high ADOM/DOC ratio predicted the general vshaped behavior but the predictions were off by $\sim 1$ order of magnitude, and contrary to the results for other metals (and for results of $\mathrm{Zn}$ of the Toledo sample), the model with a low $\mathrm{ADOM} / \mathrm{DOC}$ ratio provided better predictions in the alkaline $\mathrm{pH}$ range. Similar to $\mathrm{Ni}, \mathrm{Zn}$ was bound primarily to $\mathrm{OM}$ at low $\mathrm{pH}$ values and to $\mathrm{HFO}$ at higher $\mathrm{pH}$ values (Table 2 ). A small fraction of sorbed $\mathrm{Zn}(<4 \%)$ was also found on $\mathrm{HMO}$ surfaces. These findings agree with the sequential extraction results of Burton et al. (2003), who also reported $\mathrm{Zn}$ to be associated with primarily organic and Fe/Mn-oxide fractions of biosolids.

The results for cations showed that to a large extent the success of the model depended on assumptions regarding the reactivity of DOM. Modeling alone did not give a consistent clue as to which, of any, of the two extreme ADOM/DOC ratios would be the most realistic. In addition, it is possible that mineral-organic complexation constants are not the same 

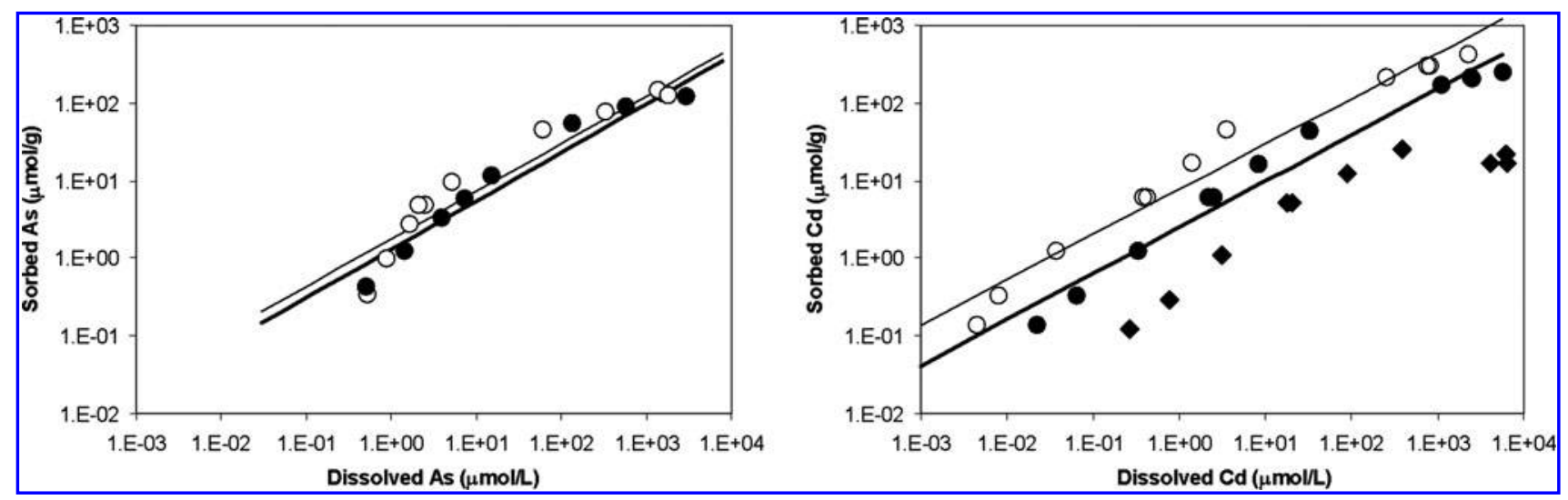

FIG. 6. Experimental (empty circles) and adjusted model (ADOM/DOC $=0.25$; filled circles) results for Toledo biosolids isotherms. Filled diamonds represent the model without OM. Thin and thick straight lines are the Freundlich models fit to experimental and modeled data, respectively.

for biosolids DOM as for natural DOM. Therefore, more detailed studies focusing on the reactivity of isolated DOM fractions with respect to proton and metal binding are needed to improve the capability of geochemical models to predict the fate of biosolids-borne trace metals in the environment.

\section{Sorption isotherms}

As expected, when total concentrations in the system increased, both the dissolved and sorbed concentrations of As and $\mathrm{Cd}$ increased (Fig. 6). The maximum sorption capacity was not achieved in these experiments. The slope of the isotherms decreased with increasing total As and Cd concentrations, but the slopes did not completely level off. The isotherms showed that the Toledo biosolids had at least $45 \mathrm{mg}$ $\mathrm{Cd} / \mathrm{g}$ and $12 \mathrm{mg} \mathrm{As} / \mathrm{g}$ sorption capacity. This sorption capacity for the Toledo sample for $\mathrm{Cd}$ was similar to the $\mathrm{Cu}$ maximum sorption capacity ( $50 \mathrm{mg} \mathrm{Cu} / \mathrm{g}$ biosolids) reported for biosolids from Alabama (Bahaminyakamwe et al., 2006).

The geochemical model fits the experimental isotherm data better for As than for $\mathrm{Cd}$. The geochemical model for $\mathrm{Cd}$ followed a similar trend as experimental data, but it underestimated the experimental sorption isotherm within 1 order of magnitude. At low Cd concentrations, $>90 \%$ of the Cd was in the sorbed phase, and as Cd concentration increased, the percentage of $\mathrm{Cd}$ sorbed decreased ultimately to half of the total available $\mathrm{Cd}$ in the system.

$\mathrm{OM}$ was the primary sorbent for $\mathrm{Cd}$ for the entire isotherm. At low Cd concentrations, $>95 \%$ of the sorbed Cd was bound to OM. As total Cd concentration in the system increased, the inorganic sites became more important; up to $22 \%$ of sorbed $\mathrm{Cd}$ was found on the inorganic sorbents within the concen- tration ranges studied. A model scenario in which the OM was completely removed showed that the biosolids still retained considerable sorption capacity for $\mathrm{Cd}$ even in the absence of OM, which is in good agreement with the findings of Hettiarachchi et al. (2003). In the scenario, without the OM, the sorbed concentrations did not continuously increase; they leveled off at a maximum sorption capacity of $2 \mathrm{mg} \mathrm{Cd} / \mathrm{g}$ biosolids. Given a certain level of sorbed concentration, the corresponding dissolved concentration was at least 1 order of magnitude higher without the OM than with OM.

Linear regression fits of experimental and modeled data to equation (2) provided reasonably good $R^{2}$ values for both As and $\mathrm{Cd}$ (Table 3). For As, Freundlich isotherm parameters $K_{\mathrm{f}}$ and $n$ estimated from modeled data were very similar to those estimated from experimental data. For Cd, Freundlich isotherm constant $n$ estimated for the modeled and experimental data were similar, but the $K_{\mathrm{f}}$ constant of the modeled isotherm was smaller than the $K_{\mathrm{f}}$ constant of the experimental isotherm.

\section{Summary and Conclusions}

In the present study, $\mathrm{pH}$-dependent leaching experiments and sorption isotherm experiments were coupled with the multisurface geochemical modeling approach to study the leaching behavior and equilibrium reactions of trace metals and As in biosolids. Biosolids samples obtained from Toledo and Chicago wastewater treatment plants had either comparable or higher concentrations of organic and inorganic sorbents compared with soils (Dijkstra et al., 2004). The multisurface geochemical modeling approach was partially successful in predicting the dissolution of trace metals and As from biosolids as a function of $\mathrm{pH}$. Further, the modeling

Table 3. Freundlich Model Parameters for the Toledo Isotherms Obtained from Laboratory ExPERIMENTS AND GeOchemical Modeling

\begin{tabular}{lcccr}
\hline & \multicolumn{2}{c}{ As } & & Cd \\
\cline { 2 - 5 } & Experimental & Geochemical model & Experimental & Geochemical model \\
\hline$n$ & 0.613 & 0.624 & 0.576 & 0.595 \\
$K_{\mathrm{f}}$ & 1.771 & 1.297 & 9.226 & 2.506 \\
$R^{2}$ & 0.927 & 0.948 & 0.983 & 0.970 \\
\hline
\end{tabular}


approach also successfully predicted (within 1 order of magnitude) the dissolved concentrations in isotherm experiments of As and $\mathrm{Cd}$. The present study showed that the multisurface geochemical model could be used to generate As and (to a lesser extent) Cd Freundlich isotherm parameters for the Toledo sample. Thus, the geochemical modeling approach holds good promise for determining biosolids Freundlich isotherm parameters; such parameters can be useful as inputs to fate and transport models that include multiple processes (e.g., plant uptake, advection, diffusion, and dispersion) and therefore allow only a limited description (such as a twoparameter Freundlich model) of the solid-liquid equilibrium partitioning of metals.

Both the modeled and experimental data indicated that As and Mo in biosolids were bound to Fe-oxides; $\mathrm{Cd}, \mathrm{Cr}$, and $\mathrm{Cu}$ were bound mainly to $\mathrm{OM}$; and as $\mathrm{pH}$ increased, the fractions of $\mathrm{Cd}$ and $\mathrm{Cu}$ bound to Fe-oxides in the biosolids matrix increased. $\mathrm{Ni}$ and $\mathrm{Zn}$ were distributed between $\mathrm{OM}$ and $\mathrm{Fe}-$ oxides, and the percentage of each fraction depended on the $\mathrm{pH}$. $\mathrm{Pb}$ was primarily bound to $\mathrm{HMO}$ at $\mathrm{pH}$ above 8 . Isotherms also showed that both organic and inorganic sites were responsible for retention of trace elements in biosolids. The model predictions for the sorption isotherms for $\mathrm{Cd}$ suggested that even in the absence of OM fraction, the biosolids may maintain a $2 \mathrm{mg} \mathrm{Cd} / \mathrm{g}$ biosolids sorption capacity. However, from modeling results, it was observed that the dissolved concentrations in absence of $\mathrm{OM}$ may still be at least 1 order of magnitude higher than with $\mathrm{OM}$ in the biosolids.

For geochemical modeling purposes, the ADOM/DOC ratio as well as the metal-organic complexation constants and the reactivity and composition of the solid-phase OM represent considerable uncertainties that need to be addressed by obtaining more information on the properties of biosolidsderived OM. The present study was not able to include in the model the dissolution/precipitation reactions; this could be an important future step that could lead to improved model predictions.

\section{Acknowledgments}

Douglas Sturtz and Jonathan Frantz from USDA-ARS are gratefully acknowledged for their help in ICP analysis. Michael Carson from the Toledo Division of Water Reclamation is gratefully acknowledged for supplying the biosolids samples. The authors also thank four anonymous reviewers for their thoughtful and detailed comments that helped to significantly improve an earlier version of the manuscript.

\section{Author Disclosure Statement}

No competing financial interests exist.

\section{References}

Alonso, E., Villar, P., Santos, A., and Aparicio, I. (2006). Fractionation of heavy metals in sludge from anaerobic wastewater stabilization ponds in southern Spain. Waste Manage. 26, 1270.

Alvarez, A.E., Monchon, M.C., Sanchez, J.C.J., and Rodriquez, M.T. (2002). Heavy metal extractable forms in sludge from wastewater treatment plants. Chemosphere 47, 765.

Amery, F., Degryse, F., Cheyns, K., De Troyer, I., Mertens, J., Merckx, R., and Smolders, E. (2008). The UV absorbance of dissolved organic matter predicts the fivefold variation in its affinity for mobilizing $\mathrm{Cu}$ in an agricultural soil horizon. Eur. J. Soil Sci. 59, 1087.

Apul, D.S., Gardner, K.H., Eighmy, T.T., Fallman, A.M., and Comans, R.N.J. (2005). Simultaneous application of dissolution/precipitation and surface complexation/surface precipitation modeling to contaminant leaching. Environ. Sci. Technol. $39,5736$.

ASTM Standard D 2216 (2005). Standard Test Methods for Laboratory Determination of Water (Moisture) Content of Soil and Rock by Mass. West Conshohocken, PA: ASTM International. Available at: www.astm.org.

Bahaminyakamwe, L., Simunek, J., Dane, J.H., Adams, J.F., and Odom, J.W. (2006). Copper mobility in soils as affected by sewage sludge and low molecular weight organic acids. Soil Sci. 171, 29.

Basta, N.T., Ryan, J.A., and Chaney, R.L. (2005). Trace element chemistry in residual-treated soil: key concepts and metal bioavailability. J. Environ. Qual. 34, 49.

Benjamin, M. (2001). Water Chemistry. New York: McGraw Hill Publishing.

Bergkvist, P. (2003). Long-term fate of sewage-sludge derived cadmium in arable soils: laboratory and field experiments, and modelling with SLAM and WHAM. Ph.D. Thesis, Swedish University of Agricultural Sciences (SLU), Uppsala, Sweden.

Boyd, S.A., and Sommers, L.E. (1990). Humic and fulvic acid fractions from sewage sludges and sludge-amended soils. In P. MacCarthy, C.E. Clapp, R.L. Malcolm, and P.R. Bloom, Eds., Humic Substances in Soil and Crop Sciences: Selected Readings. Madison, WI: ASA, p. 203.

Burton, E.D., Hawker, D.W., and Redding, M.R. (2003). Estimating sludge loadings to land based on trace metal sorption in soil: effect of dissolved organo-metallic complexes. Water Res. 37, 1394.

Davis, J.A., Coston, J.A., Kent, D.B., and Fuller, C.C. (1998). Application of the surface complexation concept to complex mineral assemblages. Environ. Sci. Technol. 32, 2820.

Dijkstra, J.J., Meeussen, J.C.L., and Comans, R.N.J. (2004). Leaching of heavy metals from contaminated soils: an experimental and modeling study. Environ. Sci. Technol. 38, 4390.

Dijkstra, J.J., Meeussen, J.C.L., and Comans, R.N.J. (2009). Evaluation of a generic multisurface sorption model for inorganic soil contaminants. Environ. Sci. Technol. 43, 6196.

Dijkstra, J.J., Meeussen, J.C.L., van der Sloot, H.A., and Comans, R.N.J. (2008). A consistent geochemical modeling approach for the leaching and transport of major and trace elements in MSWI bottom ash. Appl. Geochem. 23, 1544.

Dzombak, D.A., and Morel, F. (1990). Surface Complexation Modeling: Hydrous Ferric Oxide. New York: Wiley.

Gustafsson, J.P. (2009). Visual MINTEQ Version 2.60. Available at: www.lwr.kth.se/English/OurSoftware/vminteq.

Gustafsson, J.P., and Kleja, D.B. (2005). Modeling salt-dependent proton binding by organic soils with the NICA-Donnan and Stockholm humic models. Environ. Sci. Technol. 39, 5372.

Gustafsson, J.P., and van Schaik, J.W.J. (2003). Cation binding in a mor layer: batch experiments and modelling. Eur. J. Soil Sci. 54, 295.

Hartley, W., Edwards, R., and Lepp, N.W. (2004). Arsenic and heavy metal mobility in iron oxide-amended contaminated soils as evaluated by short- and long-term leaching tests. Environ. Pollut. 131, 495.

Haynes, R.J., Murtaza, G., and Naidu, R. (2009). Inorganic and organic constituents and contaminants of biosolids: implications for land application. Adv. Agron. 104, 165. 
Hettiarachchi, G.M., Ryan, J.A., Chaney, R.L., and La Fleur, C.M. (2003). Sorption and desorption of cadmium by different fractions of biosolids-amended soils. I. Environ. Qual. 32, 1684.

Hettiarachchi, G.M., Scheckel, K.G., Ryan, J.A., Sutton, S.R., and Newville, M. (2006). mu-XANES and mu-XRF investigations of metal binding mechanisms in biosolids. I. Environ. Qual. $35,342$.

Hsiau, P.C., and Lo, S.L. (1997). Characteristics of four alkaline biosolids produced from sewage sludge. Resour. Conserv. Recycl. 21, 185.

Ito, A., Takachi, T., Kitada, K., Aizawa, J., and Umita, T. (2001). Characteristics of arsenic elution from sewage sludge. Appl. Organomet. Chem. 15, 266.

Jaynes, W.F., Zartman, R.E., Sosebee, R.E., and Wester, D.B. (2003). Biosolids decomposition after surface applications in west Texas. J. Environ. Qual. 32, 1773.

Khai, N.M., Oborn, I., Hillier, S., and Gustafsson, J.P. (2008). Modeling of metal binding in tropical Fluvisols and Acrisols treated with biosolids and wastewater. Chemosphere 70, 1338.

Kinniburgh, D.G., van Riemsdijk, W.H., Koopal, L.K., Borkovec, M., Benedetti, M.F., and Avena, M.J. (1999). Ion binding to natural organic matter: competition, heterogeneity, stoichiometry and thermodynamic consistency. Colloid Surface A $151,147$.

Kosson, D.S., van der Sloot, H.A., Sanchez, F., and Garrabrants, A.C. (2002). An integrated framework for evaluating leaching in waste management and utilization of secondary materials. Environ. Eng. Sci. 19, 159.

Kostka, J.E., and Luther, G.W. (1994). Partitioning and speciation of solid-phase iron in salt-marsh sediments. Geochim. Cosmochim. Acta 58, 1701.

Kot, A., and Namiesńik, J. (2000). The role of speciation in analytical chemistry. Trends Anal. Chem. 19, 69.

McBride, M.B. (1994). Environmental Chemistry of Soils. New York: Oxford University Press.

McBride, M.B. (1995). Toxic metal accumulation from agricultural use of sludge: are U.S. regulations protective? I. Environ. Qual. 24, 5.

McBride, M.B., Richards, B.K., and Steenhuis, T. (2004). Bioavailability and crop uptake of trace elements in soil columns amended with sewage sludge products. Plant Soil 262, 71.

McFarland, M.J. (2001). Biosolids Engineering. New York: McGraw-Hill.

McLaren, R.G., and Clucas, L.M. (2001). Fractionation of copper, nickel, and zinc in metal-spiked sewage sludge. I. Environ. Qual. 30, 1968.

Meima, J.A., and Comans, R.N.J. (1998). Application of surface complexation precipitation modeling to contaminant leaching from weathered municipal solid waste incinerator bottom ash. Environ. Sci. Technol. 32, 688.

Merrington, G., and Smernik, R.J. (2004). Cadmium sorption in biosolids amended soils: results from a field trial. Sci. Total Environ. 327, 239.
Mijno, V., Catalan, L.J.J., Martin, F., and Bollinger, J.C. (2004). Compositional changes in cement-stabilized waste during leach tests-comparison of SEM/EDX data with predictions from geochemical speciation modeling. J. Colloid Interface Sci. $280,465$.

Milne, C.J., Kinniburgh, D.G., Van Riemsdijk, W.H., and Tipping, E. (2003). Generic NICA-Donnan model parameters for metal-ion binding by humic substances. Environ. Sci. Technol. 37, 958.

Pandeya, S.B., and Singh, A.K. (2000). Potentiometric measurements of stability constants of complexes between fulvic acid carboxylate and $\mathrm{Fe}^{3+}$. Plant Soil 223, 13.

Smith, R.M., Martell, A.E., and Motekaitis, R.J. (2003). NIST Critically Selected Stability Constants of Metal Complexes Database. Version 7.0. NIST Standard Reference Database 46. National Institute of Standards and Technology, U.S. Department of Commerce, Gaithersburg.

Sposito, G., Lund, L.J., and Chang, A.C. (1982). Trace metal chemistry in arid-zone field soils amended with sewage sludge: I. Fractionation of $\mathrm{Ni}, \mathrm{Cu}, \mathrm{Zn}, \mathrm{Cd}$, and $\mathrm{Pb}$ in solid phases. Soil Sci. Soc. Am. J. 46, 260.

Sracek, O., Bhattacharya, P., Jacks, G., Gustafsson, J. P., and von Bromssen, M. (2004). Behavior of arsenic and geochemical modeling of arsenic enrichment in aqueous environments. Appl. Geochem. 19, 169.

Tessier, A., Cambell, P.G.C., and Bisson, M. (1979). Sequential extraction procedure for the speciation of particulate trace metals. Anal. Chem. 51, 844.

Tonkin, J.W., Balistrieri, L.S., and Murray, J.W. (2004). Modeling sorption of divalent metal cations on hydrous manganese oxide using the diffuse double layer model. Appl. Geochem. 19, 29.

U.S. EPA (1999). MINTEQA2/PRODEFA2, A Geochemical Assessment Model for Environmental Systems: User Manual Supplement for Version 4.0. Available at: www.epa.gov/ceampubl/ mmedia/minteq/supple1.pdf.

van Reeuwijk, L.P. (1992). Procedures for Soil Analysis, 3rd edition. Wageningen: International Soil Reference and Information Centre.

Wen, X.H., Du, Q., and Tang, H.X. (1998). Surface complexation model for the heavy metal adsorption on natural sediment. Environ. Sci. Technol. 32, 870.

Weng, L.P., Temminghoff, E.J.M., Lofts, S., Tipping, E., and van Riemsdijk, W.H. (2002). Complexation with dissolved organic matter and solubility control in a sandy soil. Environ. Sci. Technol. 36, 4804.

Weng, L.P., Temminghoff, E.J.M., and van Riemsdijk, W.H. (2001). Contribution of individual sorbents to the control of heavy metal activity in sandy soil. Environ. Sci. Technol. 35, 4436.

Yang, X., Shang, C., Lee, W., Westerhoff, P., and Fan, C. (2008). Correlation between organic matter properties and DBP formation during chloraminaton. Water Res. 42, 2329. 